\title{
A Universal Social Minimum as a Foundation for Citizenship
}

\author{
Koy Thomson
}

\begin{abstract}
1 Introduction
This article is an argument for a 'universal social minimum', or a 'social floor' as a foundation for citizenship. The universal social minimum aims to serve a dual function. The first is to create a coherent framework that responds to the increasing social, economic and environmental vulnerabilities and risks heaped upon most of us, but especially those living in poverty. The second is to frame the arguments as a political programme, wresting the issue from technocrats and creating the possibility for political vision and will.
\end{abstract}

Obviously as a response to vulnerability and risk, the idea of a social minimum impinges on the social protection agenda. For those with a comprehensive approach to social protection, the universal social minimum could be seen as a social protection framework; for those with narrower approaches it could provide a framework within which social protection sits. The critical thing is that the social policy measures aimed at addressing vulnerability and risk are shaped from a human rights and social justice perspective, and that they work together as a whole.

This article will lay out the justification for a social minimum in human rights and social justice theory, establish and define the social minimum and then explore the synergies between the social minimum and social protection.

\section{The justification for a universal social minimum 2.1 Development in reverse}

Social and economic policies are not keeping up with the realities of vulnerability, risk and inequality as they impact on the poorest. Human lives globally are increasingly characterised by insecurity and uncertainty. The fear and risk are magnified with poverty. The benefits of economic growth do not appear to be 'trickling-down'; instead, a 'siphoningup' is concentrating wealth at the top and increasing inequality.

This is not to write off the importance of markets and incentives to generate wealth and stimulate economic growth; it is simply to recognise that some problems arise from the nature of the economic system, rather than as unfortunate side effects. Thus they are foreseeable and likely (as opposed to bad luck and rare), and as such are someone's responsibility. Examples of 'reverse development' include: shifts to low-waged unregulated, casual jobs; capitalist efficiencies creating over-supply of goods and services on the one hand, and depressing demand on the other; financial liberalisation removing the tools to manage economic risks; trade liberalisation forcing countries into global competition before they are ready, leading to deindustrialisation and dependence upon low-value and vulnerable primary commodity sectors.

The systemic and predictable nature of many of these risks and vulnerabilities challenges our assumptions that all able-bodied adults can support themselves through work, that being out of work is temporary, that work pays a living wage, and that people living in rural areas can support themselves in an increasingly hostile market. Inclusion in the global economy is not always what it is cracked up to be. Social rights are not keeping pace with market vulnerabilities.

\subsection{Inequality}

People living in poverty suffer an inequality 'double whammy'. First, they get a disproportionate share of the bad things - insecurity, risk and hardship -

compared with the rest of the population. Second, they get an inadequate share of the good things, like 
income. Globally, inequality is getting worse and this matters because of its structural nature and incompatibility with poverty reduction objectives.

Inequality directly impacts upon poverty, whether measured in absolute or relative terms. From a purely instrumental perspective, inequality matters both because it distances people at the bottom of the heap from opportunities for social and economic advance and because it undermines the overall quality and quantity of economic growth. Birdsall (2005) warns that income differentials can aggravate unfairness in the allocation of opportunities, the functioning of the political process, and efforts to improve the wellbeing of the least advantaged. Economic power means the political power to influence policies that institutionalise inequality. It is a process which turns human rights into privileges, public goods into commodities, and switches trade, aid, and economic policy towards serving the interests of the economically powerful, concentrating income, wealth and political power. Townsend and Gordon (2002) call this process 'social polarisation' and argue that this is often the critically missing context in debates about poverty and social exclusion.

Social exclusion is increasingly being used to describe 'poverty-generating' processes in developing countries. Economic, cultural, social and political factors 'deprive people of rights, valued goods and services, and the opportunities to live in accordance with their own aspirations with dignity and wellbeing' (Mander and Kumaran 2006). Such factors include discrimination on the basis of race, class, gender, age, physical ability, ethnicity and so on - in other words, deprivation caused by arbitrary and abusive relations of status and power. Tackling exclusion means redistributing social power. $A$ first step in this direction requires the establishment of a social minimum.

\subsection{Poverty and human rights}

Human rights are moral claims to equal and just treatment. In comparison to the rest of the population, people living in poverty are hugely and disproportionately without the enjoyment of human rights.

The International Bill of Rights and subsequent human rights instruments and enforcement mechanisms provide a powerful set of human rights standards, all of which have a relationship to poverty (including the right to social protection). But the connection to the argument about a social minimum is not only in the potential for litigation, or using human rights standards and principles to inform the content of the social minimum. The strong link to the social minimum is in the foundational values of human rights, most particularly autonomy, agency, and dignity.

Autonomy is the 'classical' foundational value in human rights thinking. An autonomous person must be free to rule herself, make her own choices and set her own goals which are uniquely her own. $A$ closely related value is agency. It is no good being able to set your own goals if you cannot act on them - you must have the capacity to be an active agent in pursuing your life's plans and projects. To deny people this freedom is to treat them as less than human. Human rights provide those freedoms, including the freedom provided by a basic degree of material wellbeing and security, so that people's entire lives are not taken up with anxiety, desperation and the task of physically surviving. Equal worth is also reflected in the term dignity (self-respect and selfesteem). A society that respects dignity is necessarily committed to creating the social conditions to guarantee dignity for all.

This short reflection on the foundational values of human rights shows that civil and political rights cannot fulfil their purpose if people are without basic needs:

... deprivation impedes the development of a whole range of human capabilities including the ability to fulfil life plans and participate effectively in political, economic and social life ... If basic subsistence needs are not met ... It also deprives society of the contributions of all of its members. Thus both the individual and society are impoverished by our collective failure to ensure conditions worthy of the dignity of people as both individual and social beings. (Liebenberg 2005)

At heart, dignity requires us to focus on both the individual nature of freedom and the duty of society as a whole to redress the social, political and economic basis of inequality and disadvantage. The social minimum provides that redress.

\subsection{Poverty and social justice}

So far, we have reflected on the linkages between poverty, vulnerability, inequality and human rights, touching on issues of exclusion and power along the 
way. But the argument for a universal social minimum requires a final piece: social justice. David Donnison (1998) inserts the final piece well:

Exclusion, poverty, hardship, inequality, loss of freedom ... describe different ways of looking at the same things, not separate phenomena. We cannot understand poverty or measure it unless we understand how it is related to the other things in this list. It follows that the best measures of poverty will not be single 'poverty lines' but measures which tell us something about the whole pattern of the society concerned. Inequality and exclusion are ways of describing that pattern, rather than just the situation of the poorest people. The pattern reflects the character of the whole society.

For Donnison, 'the character of the whole society' is social injustice. All of the poverty-related concepts discussed so far have their foundations in concerns for social justice. Vallentyne (2006) argues that justice is about what we morally owe one another as a matter of right. Justice concerns itself with inequalities of all kinds, be it the fairness of processes, the distribution of resources (and rights and opportunities), or putting right past wrongs. All are relevant to issues of poverty and inequality, but the most important to this discussion are questions of distribution, since the issue at stake is the lack or denial of resources, opportunities and rights of people living in poverty.

The core questions are 'to who is justice owed, what are they owed, and what pattern of distribution is owed?' (Vallentyne 2006). To this we might add 'how are people to get what they are owed?' - what political programme will deliver social justice for people living in poverty? The issue of 'to who is justice owed' is usually bound by concepts of 'citizenship'. The key concern is for those excluded arbitrarily, whether due to economic, social or political marginalisation.

What is the currency of justice? With what kinds of goods and benefits is justice concerned? This issue is at the heart of the social minimum. Some of the main contenders are resources, primary goods, capabilities, social/political status (respect) and freedom (Vallentyne 2006). All theories of social justice (including the justifications for human rights) stem from a basic question: can we objectively identify 'primary goods' whose value stems from them being absolutely fundamental or basic to human wellbeing? Social justice demands that an individual respects and realises these human goods not just for herself and her sake, but also collectively for the whole community.

Amartya Sen's capability approach argues that 'primary goods' are necessary but not sufficient. Sen's concern is that human beings can 'be', 'do', and become what they would value, not simply survive which is the implication of a focus on primary goods. For capability champions, the currency of justice has to be the freedom to achieve, or capabilities. $A$ desired 'being', 'doing' or 'becoming' requires both the means to achieve and the freedom to achieve. The primary goods and services that make up the means to achieve include services like education and goods such as income and assets. But the freedom to achieve requires things like protection from discrimination, positive social networks, respect, autonomy, self-awareness and agency, political and civil rights, and institutions that guarantee equal treatment. If a just society provides the capability to be fully human, then justice in practice must involve distribution of resources (income and wealth), goods, services, human rights, power and opportunities. For Martha Nussbaum (2003), the concept of capability must lead to a solid constitutional and political programme that recognises the moral equality of all persons and guarantees capabilities as rights. This argument appears consistent with a social minimum.

\subsection{The universal social minimum}

Human rights and social justice thinking are both concerned with actions to ensure that everyone has an equal chance of living a life of dignity and fulfilling their human potential, as well as considerations about what we morally owe one another as a matter of right. Both are rooted in ideas about what is intrinsically important to each individual's wellbeing. Human rights demand that these things are respected, protected, promoted and fulfilled in order that each individual functions as a free and equal member of society. Social justice demands a fair share of these intrinsically important things and a fair distribution of burdens and benefits in society. The social minimum, while initially 'prioritarian', aims progressively at universalism, and through engaged citizenship at full equality of opportunity. Human rights and social justice are for everyone, not just people living in poverty. But social justice demands prioritising the worst off. 
The social minimum must go beyond addressing the most brute deprivations, and provide a floor of dignity and a basic standard of living designed to bring people to the point materially and politically where, as capable citizens, they contribute to the shaping of political and social goals. Deliberative and democratic debate is thus an integral part of the social minimum itself.

The social minimum, while not providing a complete solution to fulfilling human potential and social justice goals, must be a major step towards that goal. Thus, the social minimum must comprehensively address what this article has described as the structural factors which make people vulnerable to poverty and keep them vulnerable through lifetimes and even generations:

- Human rights violations

- Social polarisation and inequality

- Insecurity and shocks

- Exclusion

- Market vulnerability

- Lack of political participation

The social minimum would be a clear constitutional and political guarantee which responds to these six factors. To extend Stuart White's (2004) definition of the 'civic minimum':1

The social minimum is the basic means including resources, opportunities, rights and power to lead an adequately decent and dignified life, and to participate and advance as a free and equal member in society.

This definition, in containing the idea of 'progression' and the idea of supporting people to the point where they can exercise agency, establishes the social minimum as a foundation for citizenship. Basic needs approaches are insufficient to satisfy the demands of social justice. If social protection cannot take people beyond the physical interests shared with animals, how is it truly underpinning the flourishing of human potential?

The social minimum seeks to reduce and mitigate inequality in:

- Resources: income and assets (wages, basic income, income-generating assets such as land and credit resources)
- Rights and access to essential services (free basic education and healthcare, food security, housing, and so on)

- Opportunities (jobs, training, skills, participation in markets and social institutions)

- Power (decision-making, participation in policy discussions and formulation, budget allocations, etc.)

\section{The social minimum and social protection}

Putting all of these arguments together, the social minimum would seek to provide:

1 Protection from vulnerability and hardship, through relief, safety nets, social assistance (child, disability, old age benefits), public works and free basic services (education, health, housing, nutrition)

2 Prevention of deprivation and smoothing of production and consumption falls, through social insurance, social assistance, public works and employment guarantees and protection, and risk reduction.

3 Security to take livelihood and economic risks and promote opportunity, through a basic income, access to productive and income-generating resources such as credit, land, common property resources, tenure security, knowledge and extending social protection to the informal sector.

4 Freedom from the structural causes of vulnerability, such as discrimination, stigma, domestic and other violence, but also processes of 'commodification' that make critical services such as electricity and water unaffordable to people living in poverty.

5 Transformation in social relations and expanded democratic space, such that deliberation around the social minimum and the shaping of economic and social policy are constitutive of the social minimum itself. If programmes within the social minimum are to work, they must be accompanied by the right to information, transparency, participatory budgeting and auditing, popular education on rights and entitlements, and so on.

The social minimum can find support in a wide range of theories of justice and international human rights agreements (White 2004). The social minimum is also very close in conception (and content) to the 'extended' perspective on social security as expressed by the 
'Report of the Committee of Inquiry into a Comprehensive System of Social Security for South Africa' (Taylor Committee 2002), the anti-poverty measures detailed in the Indian Government's 'Common Minimum Programme' (Government of India 2004), the UN Commission on Social Development (UNESCO 2001), 'Transformative social protection' (Devereux and Sabates-Wheeler 2004) and the ILO's 'progressive universalism'. In addition, groups such as the UK-based 'Grow-up Free from Poverty' coalition, who are campaigning on social protection, recognise the need to situate their priorities within a broader transformative programme, including a social minimum.

The conception of the universal social minimum resonates with the argument for 'transformative

\section{Note}

1 See White (2004) 'We define a "social minimum" as that bundle of resources which suffices in the circumstances of a given society to enable someone to lead a minimally decent life'.

\section{References}

Birdsall, N. (2005) 'Why Inequality Matters in a Globalising World', paper presented for the WIDER Annual Lecture, Helsinki, 26 October

Devereux, S. and Sabates-Wheeler, R. (2004) Transformative Social Protection, IDS Working Paper 232, Brighton: IDS

Donnison, D. (1998) Policies for a Just Society, Basingstoke: Macmillan Press

Government of India (2004) National Common Minimum Programme of the Government of India, May, http//pmindia.nic.in (Prime Minister of India website)

Liebenberg, S. (2005) 'The Value of Human Dignity in Interpreting Socio-Economic Rights', South African Journal on Human Rights 21.1: 1-31

Mander, H. and Kumaran, M. (2006) Social Exclusion in ICDS: A Sociological Whodunit? A Research Study, India: CARE India

Nussbaum, M. (2003) 'Capabilities as Fundamental Entitlements: Sen and Social Justice', Feminist Economics 9.2-3: 33-59 social protection', which suggests both a 'politically live' entry point for advocacy around the social minimum (social protection policy), and a way for 'social protection' to grip the mainstream political imagination. The social minimum can also find justification in human rights standards (while not the same thing as minimum core obligations), in that the components of the social minimum are recognised human rights. An argument could be made therefore that the social minimum should itself be universal.

How the social minimum is applied depends upon national context. Advocates of social protection would do their cause well to open the civil and political space for these broader debates.
Taylor Committee (2002) Transforming the Present Protecting the Future: Report on the Committee of Inquiry into a Comprehensive System of Social Security for South Africa, Pretoria: Department of Social Development

Townsend, P. and Gordon, D., eds (2002) World Poverty; New Policies to Defeat an Old Enemy, Bristol: Policy Press

UNESCO (2001) Enhancing Social Protection and Reducing Vulnerability in a Globalizing World: Report of the Secretary General, Economic and Social Council 39th Session 2001, United Nations Educational, Scientific and Cultural Organisation

Vallentyne, P. (2006) 'Distributive Justice', in Robert Goodin, Philip Pettit and Thomas Pogge (eds) Companion to Contemporary Political Philosophy, Oxford: Blackwell Publishers

White, S. (2004) 'Social Minimum', Stanford Encyclopaedia of Philosophy, Stanford: Stanford University 